\title{
Ixabepilone: a new chemotherapeutic option for refractory metastatic breast cancer
}

\author{
Shannon Puhalla \\ Adam Brufsky \\ UPMC Magee-Womens Cancer \\ Program, University of Pittsburgh, \\ Pittsburgh, Pennsylvania, USA
}

Correspondence: Adam Brufsky UPMC Cancer Center Magee-Womens Hospital, 300 Halket Street, Pittsburgh, PA I52I3, USA

Tel + I 4I264I 6500

Fax + | 4I2 64| 646I

Email brufskyam@upmc.edu

\begin{abstract}
Taxane therapy is commonly used in the treatment of metastatic breast cancer. However, most patients will eventually become refractory to these agents. Ixabepilone is a newly approved chemotherapeutic agent for the treatment of metastatic breast cancer. Although it targets microtubules similarly to docetaxel and paclitaxel, ixabepilone has activity in patients that are refractory to taxanes. This review summarizes the pharmacology of ixapebilone and clinical trials with the drug both as a single agent and in combination. Data were obtained using searches of PubMed and abstracts of the annual meetings of the American Society of Clinical Oncology and the San Antonio Breast Cancer Symposium from 1995 to 2008. Ixapebilone is a semi-synthetic analog of epothilone B that acts to induce apoptosis of cancer cells via the stabilization of microtubules. Phase I clinical trials have employed various dosing schedules ranging from daily to weekly to 3 -weekly. Dose-limiting toxicites included neuropathy and neutropenia. Responses were seen in a variety of tumor types. Phase II studies verified activity in taxane-refractory metastatic breast cancer. The FDA has approved ixabepilone for use as monotherapy and in combination with capecitabine for the treatment of metastatic breast cancer. Ixabepilone is an efficacious option for patients with refractory metastatic breast cancer. The safety profile is similar to that of taxanes, with neuropathy and neutropenia being dose-limiting. Studies are ongoing with the use of both iv and oral formulations and in combination with other chemotherapeutic and biologic agents.
\end{abstract}

Keywords: ixabepilone, epothilone, metastatic breast cancer, taxane-refractory

\section{Introduction}

Although great strides have been made in the treatment of breast cancer, once metastatic, cure is unlikely. There are many agents available to treat metastatic breast cancer (MBC), and decisions on treatment must take into account the balance between efficacy and tolerability. Although, there are many new biological agents in clinical trials, chemotherapy is still an important backbone of the treatment. The recent approval of new agents has added to the repertoire available for the treatment of MBC (Gradishar et al 2005; Perez et al 2007; Thomas et al 2007).

The taxanes are the mainstays of chemotherapy for MBC. However, because all patients will eventually become refractory to these, new strategies are needed for taxane-refractory MBC. One drug that has shown efficacy both preclinically and clinically in patients resistant to docetaxel or paclitaxel is ixabepilone (BMS-247550). This drug fills an important void in chemotherapeutic options for patients.

\section{Pharmacology of ixapebilone}

Ixapebilone is in the epothilone class of chemotherapeutic drugs. Epothilones were initially discovered when fungicidal activity was observed by the myxobacterium Sorangium cellolosum and later these agents were found to interact with and stabilize microtubules (Bollag et al 1995; Gerth et al 1996). Microtubules help form 
the cytoskeleton and have vital roles in various cellular processes including cell signaling and mitosis. Microtubules are made up of 2 subunits, $\alpha$ and $\beta$. Microtubules have been an attractive target for many chemotherapeutic drugs, which exert their cytotoxic effects via microtubule stabilization or destabilization (Jordan et al 2004). Ixapebilone is a semisynthetic analog of epothilone B, created by the substitution of an azide group for oxygen in the macrolide ring (Fumoleau et al 2007) (Figure 1). Similar to taxanes, epothilones exert their effect by binding to and subsequently polymerizing and stabilizing microtubules, thus preventing mitosis and resulting in apoptosis (Bollag et al 1995). Epothilones specifically bind to $\beta$-tubulin, although the exact binding site is not known (Giannakakou et al 2000). Despite the fact that epothilones bind close to or at the paclitaxel binding site on tubulin (Nogales et al 1995; Ojima et al 1999; Giannakakou et al 2000), there are also data from yeast studies to suggest that the binding of epothilones to tubulin and the subsequent microtubule formation may be distinct from that of paclitaxel (Bode et al 2002). Another important difference is that epothilones have been shown to have activity both preclinically and clinically in taxane resistance, likely due to the fact that the epothilones are not substrates for P-glycoprotein or MRP-1 and are active in $\beta$-tubulin mutations (He et al 2001a; Lee et al 2006). MDR-1 drug transporter expressing

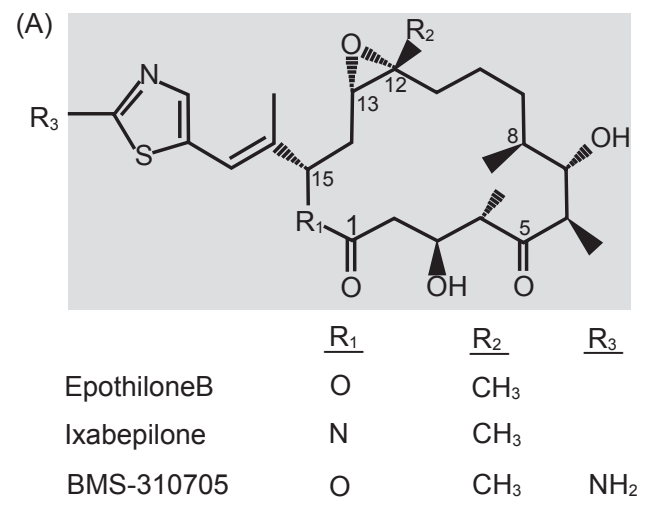

(B)

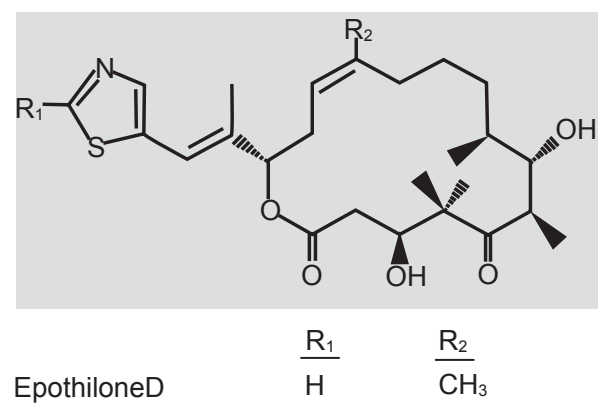

tumors are also sensitive to epothilones (McDaid et al 2002). In breast cancer cell lines and xenograft models, including those with multidrug resistance, ixapebilone has been shown to have cytotoxicity values ranging from 1.4 to $45 \mathrm{nM}$ and has improved cytotoxicity over paclitaxel (Lee et al 2001, 2006). Both an iv and oral formulation of ixabepilone have undergone clinical studies, although it is the iv form that has been approved for the treatment of breast cancer. Further trials with the oral formulation are awaited.

Cell lines resistant to epothilones have been reported (Giannakakou et al 2000; He et al 2001b). The resistance is felt to be secondary to point mutations in the $\beta$-tubulin subunit, rather than MDR1 expression. These cells lines of various tumor types including ovarian and nonsmall-cell lung cancers have been to shown to exhibit resistance to other taxanes as well. It has been shown that these point mutations lead to less endogenous microtubule stabilization (He et al 2001a). These cell lines resistant to epothilones have also been found to have slower growth, which could be secondary to the endogenously more stable microtubules or could be due to an additional mechanism.

Pharmacokinetic studies with ixabepilone given on a daily dosing schedule have demonstrated a rapid 1-log decline after drug infusion, later followed by a prolonged elimination phase, not unlike taxanes (Abraham et al 2003).
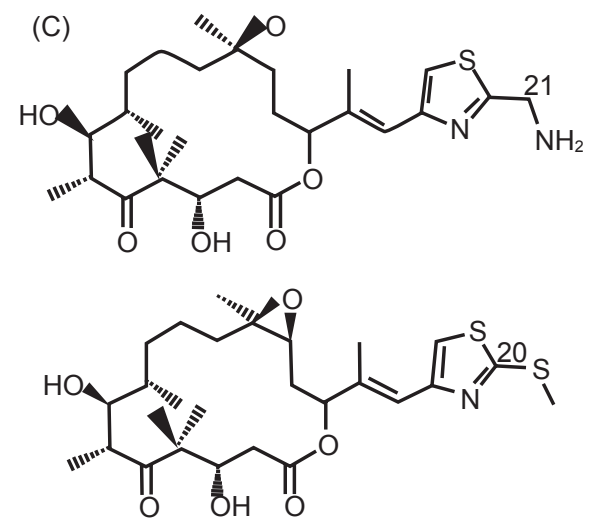

Figure I Chemical structures of the epothilones under clinical development. (A) Structure of epothilone B, ixabepilone, and BMS-3 I0705. (B) Structure of epothilone D. (C) Structure of epothilone D second generation. From Fumoleau P, Coudert B, Isambert N, et al. 2007. Novel tubulin-targeting agents: anticancer activity and pharmacologic profile of epothilones and related analogues. Ann Oncol, I8(Suppl 5):v9-15, by permission of Oxford University Press @ 2007. 
The mean half-life of the drug was 16.8 hours. Clearance was rapid, dose-independent, and not associated with body weight or surface area. Dosing every 21 days showed a similar plasma concentration curve and independence of clearance, elimination, and dose (Mani et al 2004; Gadgeel et al 2005). The mean half-life was 38.5 hours at a dose of $40 \mathrm{mg} / \mathrm{m}^{2}$ given every 21 days (Mani et al 2004).

Pharmacodynamic studies with daily dosing did not show any correlation between area under the curve (AUC) and neutropenia (Abraham et al 2003). Similarly, there was no correlation with AUC and neutropenia in the 21-day dosing schedule (Mani et al 2004). However, the percentage change in absolute neutrophil count was significantly negatively correlated with increasing doses of ixabepilone (Gadgeel et al 2005). Pharmacodynamic studies exploring microtubule bundle formation and the subsequent effects on plasma ixabepilone concentration and extent of neutropenia have been performed (McDaid et al 2002; Mani et al 2007). Microctubule bundle formation is a surrogate for ixabepilone binding to $\beta$-tubulin and drug binding increases with greater ixabepilone concentration. This binding is correlated with AUC. Interestingly, it has been shown that there were more tumor cells with microtubule bundle formation than peripheral blood mononuclear cells after ixabepilone dosing (Mani et al 2007). The degree of neutropenia has been found to be correlated with the extent of microtubule bundle formation in peripheral blood mononuclear cells.

\section{Clinical trials with ixabepilone Phase I studies (Table I)}

Numerous phase I trials have evaluated the optimum dose and toxicity with ixabepilone. There have been numerous dosing schedules in both oral and iv formulations used in these trials. The earliest phase I trial was reported by Awada et al (2001) and employed a weekly iv dosing schedule. There were various tumor types in this study including breast cancer. At the time when preliminary results were presented, the current dose level was $30 \mathrm{mg} / \mathrm{m}^{2} /$ week. Responses included stable disease in patients who were previously treated with a taxane with toxicities including fatigue, anorexia, arthralgia/ myalgia, neuropathy, and myelosuppression. Another phase I study using weekly dosing has been presented (Burris et al 2002). In this study the maximum tolerated dose (MTD) was $25 \mathrm{mg} / \mathrm{m}^{2} /$ week. Although there was minimal neutropenia, grade 3 toxicities included fatigue, nausea, diarrhea, myalgia/arthralgia, and neuropathy. This study initially used a 30-minute infusion, but was later amended to allow for a 1-hour infusion time, as well as a 3 weeks on, 1 week off dosing schedule in attempts to reduce neuropathy. Responses were seen in patients who had previously received taxane therapy. Hao et al (2002) explored continuous weekly dosing in another phase I trial. In this study, dose-limiting toxicities were grade 3 fatigue and grade 4 neutropenia at the $20 \mathrm{mg} / \mathrm{m}^{2}$ and $30 \mathrm{mg} / \mathrm{m}^{2}$ dose levels. Neuropathy was more frequent in patients who were heavily pretreated. Decreases in tumor markers were seen in taxane-refractory patients.

The use of 3-weekly dosing was also evaluated in the phase I setting. The earliest report was the preliminary data of Spriggs et al (2001). In this trial, a 1-hour infusion of ixabepilone was given to patients in dose levels ranging from $7.4 \mathrm{mg} / \mathrm{m}^{2}$ to $65 \mathrm{mg} / \mathrm{m}^{2}$. MTD was determined to be $50 \mathrm{mg} / \mathrm{m}^{2}$. Dose-limiting toxicities included grade 3 arthralgias and myalgias, grade 3 neuropathy, grade 4 neutropenia, febrile neutropenia, pneumococcal sepsis, and 1 death. Antitumor activity was seen again in taxane pretreated patients and a complete response was seen in a patient with ovarian cancer. Another phase I study using a 1-hour infusion every 3 weeks also determined the MTD to be $50 \mathrm{mg} / \mathrm{m}^{2}$ (Aghajanian et al 2007). In this study, the most common toxicities limiting dose were neutropenia, stomatitis, myalgia, and arthralgia. A 3-hour infusion time was also investigated in this trial and no dose-limiting toxicities (DLTs) were seen at doses less than $50 \mathrm{mg} / \mathrm{m}^{2}$ when the drug was administered over 3 hours. Eight patients attained an objective response, many of whom had previously received taxane therapy. Mani et al (2004) performed a phase I study using 3-weekly dosing with 1-hour infusion times. The recommended phase II dose of ixabepilone was determined to be $40 \mathrm{mg} / \mathrm{m}^{2}$. Similarly to previous trials, the dose-limiting toxicities included grade 4 and febrile neutropenia; however, grade 3 abdominal pain, nausea, and vomiting were also seen. A Japanese phase I trial using a 3 -hour infusion every 3 weeks also determined the tolerable dose of ixabepilone to be $40 \mathrm{mg} / \mathrm{m}^{2}$ (Shimizu et al 2008); DLT was grade 4 neutropenia. There were no objective responses, but over two-thirds of patients had stable disease. Linear pharmacokinetics were observed.

A dose of $40 \mathrm{mg} / \mathrm{m}^{2}$ dose was again verified as the MTD in a phase I study in patients with refractory, advanced solid tumors and the DLT was neutropenia (Gadgeel et al 2005). Grade 1 and 2 neuropathy was observed in 3 out of 5 patients who received greater than $28.6 \mathrm{mg} / \mathrm{m}^{2}$ for at least 2 cycles. Fatigue was also commonly seen. No patients met criteria for partial responses; however, there were minor responses and stable disease was seen. Pharmacokinetics were linear and there was evidence to suggest that there was a correlation 
Table I Summary of phase I studies

\begin{tabular}{|c|c|c|c|c|}
\hline Study & Dose/dosing schedule & $\begin{array}{l}\text { Maximum tolerated } \\
\text { dose }\end{array}$ & $\begin{array}{l}\text { Dose-limiting or grade } 3 / 4 \\
\text { toxicities }\end{array}$ & Activity \\
\hline Awada et al $200 \mathrm{I}$ & Weekly & $\begin{array}{l}\text { Not yet determined; } \\
\text { Enrolling at } 30 \mathrm{mg} / \mathrm{m}^{2 /} \\
\text { week }\end{array}$ & Grade 3 sensory neuropathy & $\begin{array}{l}\text { Stable disease seen in multiple } \\
\text { tumor types }\end{array}$ \\
\hline Burris et al 2002 & Weekly & $25 \mathrm{mg} / \mathrm{m}^{2} /$ week & $\begin{array}{l}\text { Cumulative sensory neu- } \\
\text { ropathy; Grades } 3 / 4 \text { fatigue, } \\
\text { nausea, diarrhea, myalgia/ } \\
\text { arthralgia }\end{array}$ & $\begin{array}{l}\text { Partial and minor responses } \\
\text { seen in multiple tumor types }\end{array}$ \\
\hline Hao et al 2002 & Weekly & $\begin{array}{l}\text { Enrolling at } 20 \\
\mathrm{mg} / \mathrm{m}^{2} / \text { week in heavily } \\
\text { pretreated patients } \\
\text { and } 30 \mathrm{mg} / \mathrm{m}^{2} / \text { week in } \\
\text { minimally pretreated } \\
\text { patients }\end{array}$ & $\begin{array}{l}\text { Grade } 3 \text { fatigue, Grade } 4 \\
\text { neutropenia }\end{array}$ & $\begin{array}{l}\text { Minor response in melanoma } \\
\text { patient, tumor marker decline } \\
\text { in taxane-refractory ovarian } \\
\text { and prostate cancer patients }\end{array}$ \\
\hline Spriggs et al 200I & Q 3 weeks; I-hour infusion & $50 \mathrm{mg} / \mathrm{m}^{2}$ & $\begin{array}{l}\text { Grade } 3 \text { neuropathy, Grade } 4 \\
\text { neutropenia with sepsis and } \\
\text { death, Grade } 3 \text { myalgia/ } \\
\text { arthralgia }\end{array}$ & $\begin{array}{l}\text { Complete response in patient } \\
\text { with paclitaxel-refractory } \\
\text { ovarian cancer, also partial } \\
\text { responses and stable disease } \\
\text { seen in multiple tumor types }\end{array}$ \\
\hline Mani et al 2004 & Q 3 weeks; I-hour infusion & $\begin{array}{l}50 \mathrm{mg} / \mathrm{m}^{2} ; \text { recom- } \\
\text { mended phase II dose } \\
40 \mathrm{mg} / \mathrm{m}^{2}\end{array}$ & $\begin{array}{l}\text { Sepsis and death, Grade } \\
4 \text { neutropenia, Grade } 3 \\
\text { abdominal pain/nausea/vom- } \\
\text { iting, Grade } 3 \text { neoropathy }\end{array}$ & $\begin{array}{l}4 \text { patients with objective } \\
\text { partial and minor responses, } \\
\text { responses include taxane- } \\
\text { refractory disease }\end{array}$ \\
\hline Gadgeel et al 2005 & Q 3 weeks; I-hour infusion & $40 \mathrm{mg} / \mathrm{m}^{2}$ & $\begin{array}{l}\text { Grade } 4 \text { neutropenia, } \\
\text { neutropenic sepsis, grade } \\
3 \text { nausea/emesis, grade } 4 \\
\text { myalgias, grade } 3 \text { fatigue, } \\
\text { grade } 4 \text { diarrhea, grade } 3 \text { and } \\
4 \text { thrombocytopenia }\end{array}$ & $\begin{array}{l}\text { Tumor shrinkage not meeting } \\
\text { criteria for partial response, } \\
\text { stable disease in multiple } \\
\text { tumor types }\end{array}$ \\
\hline Shimizu et al 2008 & Q 3 weeks; 3-hour infusion & $40 \mathrm{mg} / \mathrm{m}^{2}$ & $\begin{array}{l}\text { Grade } 4 \text { neutropenia, grade } \\
3 \text { nausea, vomiting, and } \\
\text { dehydration }\end{array}$ & Stable disease \\
\hline Aghajanian et al 2007 & $\begin{array}{l}\text { Q } 3 \text { weeks; I-hour and 3-hour } \\
\text { infusion }\end{array}$ & $50 \mathrm{mg} / \mathrm{m}^{2}$ & $\begin{array}{l}\text { Neutropenic infection and } \\
\text { death, death from pneumonia } \\
\text { and sepsis, grade } 3 \text { sen- } \\
\text { sory neuropathy, grade } 3 / 4 \\
\text { nausea/vomiting, grade } 3 / 4 \\
\text { fatigue, grade } 3 / 4 \text { myalgia/ } \\
\text { arthralgia }\end{array}$ & $\begin{array}{l}\text { Complete and partial } \\
\text { responses in multiple tumor } \\
\text { types and taxane-pretreated } \\
\text { patients }\end{array}$ \\
\hline Thambi et al 2003 & Daily for 3 days every 21 days & $\begin{array}{l}\text { Recommended phase } \\
\text { II dose: } 8 \mathrm{mg} / \mathrm{m}^{2} / \text { day } \mathrm{x} \\
3 \text { days }\end{array}$ & $\begin{array}{l}\text { Grade } 3 \text { leukopenia, grade } 4 \\
\text { neutropenia, grade } 3 \text { throm- } \\
\text { bocytopenia, grade } 3 \text { nausea, } \\
\text { grade } 3 / 4 \text { vomiting, grade } 3 \\
\text { anorexia }\end{array}$ & $\begin{array}{l}\text { Stable disease, nonconfirmed } \\
\text { tumor shrinkage }\end{array}$ \\
\hline Abraham et al 2003 & Daily for 5 days every 21 days & $\begin{array}{l}\text { Recommended phase } \\
\text { II dose: } 6 \mathrm{mg} / \mathrm{m}^{2} / \text { day } \mathrm{x} \\
5 \text { days }\end{array}$ & $\begin{array}{l}\text { Grade } 4 \text { neutropenia, grade } \\
3 \text { fatigue, grade } 3 \text { mucositis, } \\
\text { grade } 3 \text { anorexia }\end{array}$ & $\begin{array}{l}\text { Partial responses including } \\
\text { taxane-refractory patients, } \\
\text { reduction in CA-I } 25 \text { in ovar- } \\
\text { ian cancer patients }\end{array}$ \\
\hline Zhuang et al 2005 & Daily for 3 days every 21 days & $\begin{array}{l}\text { Recommended phase } \\
\text { II dose: } 8-10 \mathrm{mg} / \mathrm{m}^{2} / \\
\text { day } \times 3 \text { days }\end{array}$ & $\begin{array}{l}\text { Grade } 4 \text { neutropenia, grade } \\
3 \text { fatigue, grade } 3 \text { hyponatre- } \\
\text { mia, grade } 3 \text { anorexia, grade } \\
3 \text { ileus, grade } 3 \text { stomatitis, } \\
\text { grade } 3 \text { emesis }\end{array}$ & $\begin{array}{l}\text { Prolonged stable disease in } \\
\text { multiple tumor types }\end{array}$ \\
\hline
\end{tabular}


between the change in neutrophil count and the time at which the ixabepilone plasma concentration was $>15 \mathrm{ng} / \mathrm{mL}$.

In attempts to augment the degree of neurotoxicity observed with 3-weekly dosing, daily administration of ixabepilone was evaluated in the phase I setting. Less neuropathy has been observed in daily compared with 3-weekly dosing. Abraham et al (2003) examined a dosing schedule of treatment daily for 5 consecutive days, with 21-day dosing intervals (Abraham et al 2003). Ixabepilone was given as a 1-hour infusion. Most patients had received prior taxane therapy and half had received $\geq 6$ prior lines of treatment. MTD was $6 \mathrm{mg} / \mathrm{m}^{2}$. Higher doses $\left(8 \mathrm{mg} / \mathrm{m}^{2}\right)$ were complicated with neutropenia despite filgrastim support. Neurotoxicity was generally mild and no grade 3 or 4 neuropathy was observed. Five out of 27 patients enrolled achieved a partial response, and these patients had received prior taxane therapy. Preliminary data presented explored a daily dosing schedule given every 3 days where the recommended phase II dose was $8 \mathrm{mg} / \mathrm{m}^{2}$ for 3 days, with cycles every 21 days (Thambi et al 2003). A published report of a daily dosing schedule for 3 days also determined the MTD to be at a dose of $8 \mathrm{mg} / \mathrm{m}^{2} /$ day. This was given as a 1 -hour infusion and similarly to the Abraham study, the DLT was neutropenia and there were no cases of dose-limiting neurotoxicity (Zhuang et al 2005). Seventeen of the 26 enrolled patients had received prior taxane therapy and the median number of prior therapies received was $\geq 4$. Although no responses were observed in this trial, patients with renal cell carcinoma, ovarian cancer, and primary peritoneal mesothelioma had prolonged stable disease up to 28 months.

Numerous phase I studies have also evaluated the toxicities associated with ixabepilone given in combination with other chemotherapeutic and biologic agents (Plummer et al 2002; Anderson et al 2004; Bunnell et al 2006; Hensley et al 2007). Preliminary results of a study exploring the use of ixabepilone in combination with carboplatin revealed partial responses in patients with breast cancer as well as neuroendocrine cancer (Plummer et al 2002). Some patients also achieved stable disease. Patients were relatively chemotherapy-naïve as only up to 2 prior therapies were allowed. DLT was reached at $40 \mathrm{mg} / \mathrm{m}^{2}$ of ixabepilone and an AUC of 5 for carboplatin. A phase I/II study conducted in patients with $\mathrm{MBC}$ evaluated the combination of ixabepilone with capecitabine (Bunnell et al 2006). Eligible patients had received prior taxane and anthracycline-based treatment in the adjuvant or metastatic but could not have received greater than 3 prior regimens for metastatic disease. Two treatment schedules were evaluated; a single 3-hour infusion or daily therapy given over 1 hour for 3 days every 21 days. The recommend phase II dose for ixabepilone was determined to be $40 \mathrm{mg} / \mathrm{m}^{2}$ as a single infusion and for capecitabine was $2000 \mathrm{mg} / \mathrm{m}^{2}$ given on days $1-14$ every 3 weeks. Nearly half of the patients had 2 or more therapies in the metastatic setting. Fifteen of 50 enrolled patients achieved a complete (1 patient) or partial response (14 patients) yielding an overall response rate of $30 \%$. Responses had a median duration of nearly 7 months.

\section{Phase II studies in breast cancer (Table 2)}

Based on ample evidence of response and safety in early trials, various phase II studies were designed for patients with varying levels of previous therapies. Three published phase II trials used a daily dosing schedule. Low et al (2005) used a $6 \mathrm{mg} / \mathrm{m}^{2} /$ day dosing schedule on days $1-5$ every 3 weeks in patients with taxane-refractory breast cancer. A total of 37 patients were enrolled and 43\% had received between 3 and 9 prior chemotherapy regimens in the metastatic setting. The objective response rate (ORR) was 22\% and patients received a median of 4 cycles (range 1-11 cycles) with a median time to progression of 80 days for all subjects. An additional 35\% of patients had stable disease for at least 6 weeks. Toxicities were generally mild. Twelve patients required dose reductions secondary to toxicities including neuropathy, diarrhea, fatigue, neutropenia, and myalgia. Only 1 patient developed grade 3 neuropathy, although mild neuropathy (grades 1 or 2 ) was frequent $(83 \%$ of total subjects).

Another phase II study examined a daily dosing schedule for 5 consecutive days at a dose of $6 \mathrm{mg} / \mathrm{m}^{2} /$ day given every 21 days (Denduluri et al 2007a). Patients in this trial were taxane-naïve; however, any number of non-taxane prior therapies was allowed. Of the 23 patients enrolled, $70 \%$ had prior chemotherapy, which was primarily adjuvant anthracycline. ORR was 57\%. Stable disease for at least 6 weeks was achieved in $26 \%$. Median time to progression was 5.5 months, and for partial responders, the median duration of response was 5.6 months. Four patients had toxicity necessitating removal from study (grade 3 weight loss, grade 3 motor neuropathy, prolonged autonomic neuropathy, and grade 2 fatigue) and dose reductions occurred in 4 patients (prolonged neutropenia, neuropathy, and fatigue). Severe neuropathy was infrequent with $13 \%$ having grade 2 sensory neuropathy, $4 \%$ grade 2 motor neuropathy, no patients with grade 3 sensory neuropathy, and 1 patient with grade 3 motor neuropathy. The same group performed a small study using daily dosing but with 3 consecutive days of therapy at initial 
doses of $8 \mathrm{mg} / \mathrm{m}^{2} /$ day which was titrated up to $10 \mathrm{mg} / \mathrm{m}^{2} /$ day if tolerated (Denduluri et al 2007b). Of the 12 patients enrolled, all had received previous taxanes. Median number of previous therapies in the metastatic setting was 3.5. The treatment had an acceptable safety profile; however, no complete or partial responses were seen and the study was stopped. Possible explanations for the lack of response may be decreased dose intensity in comparison with other studies with daily dosing.
There have also been numerous phase II studies with 3-weekly dosing in patients with $\mathrm{MBC}$, in both taxane-naïve and taxane-refractory patients. Perez et al (2007) examined the efficacy of ixabepilone in a heavily pretreated patient population which had received prior anthracycline, taxane, and capecitabine therapies. Dose was $40 \mathrm{mg} / \mathrm{m}^{2}$ given as a 3-hour infusion every 3 weeks. This was the third line of treatment in the metastatic setting for $88 \%$ of the 126 patients enrolled. An independent radiology facility assessed ORR at

Table 2 Summary of phase II studies in metastatic breast cancer

\begin{tabular}{|c|c|c|c|c|c|}
\hline Study & $\begin{array}{l}\text { Number of } \\
\text { patients }\end{array}$ & Dosing schedule & $\begin{array}{l}\text { Objective response } \\
\text { rate }\end{array}$ & Survival endpoints & $\begin{array}{l}\text { Selected grade } 3 / 4 \\
\text { toxicities (\%) }\end{array}$ \\
\hline $\begin{array}{l}\text { Low et al 2005; } \\
\text { Prior taxane }\end{array}$ & 37 & $\begin{array}{l}6 \mathrm{mg} / \mathrm{m}^{2} / \text { day on days } \\
\mathrm{I}-5 \text { every } 3 \text { weeks }\end{array}$ & $\begin{array}{l}22 \%(95 \% \mathrm{Cl}, 9.8 \%- \\
38.2 \%)\end{array}$ & $\begin{array}{l}\text { Median time to } \\
\text { progression } 80 \text { days }\end{array}$ & $\begin{array}{l}\text { Neutropenia (35\%) } \\
\text { Febrile neutropenia } \\
\text { (I4\%) } \\
\text { Thrombocytopenia (8\%) } \\
\text { Fatigue (I3\%) } \\
\text { Sensory neuropathy (3\%) } \\
\text { Myalgia/arthralgia (3\%) } \\
\text { Nausea (5\%) } \\
\text { Constipation (I } \%) \\
\text { Diarrhea (5\%) }\end{array}$ \\
\hline $\begin{array}{l}\text { Denduluri et al } \\
\text { 2006; Prior } \\
\text { taxane }\end{array}$ & 12 & $\begin{array}{l}8 \mathrm{mg} / \mathrm{m}^{2} / \text { day on } \\
\text { days I-3 every } 3 \\
\text { weeks (increased to } \\
10 \mathrm{mg} / \mathrm{m}^{2} / \text { day if no } \\
\text { toxicity) }\end{array}$ & $\begin{array}{l}\text { No objective responses; } \\
\text { I0 patients with stable } \\
\text { disease for } \geq 6 \text { weeks }\end{array}$ & $\begin{array}{l}\text { Median time } \\
\text { to progression } \\
2.7 \text { months }\end{array}$ & $\begin{array}{l}\text { Neutropenia (I7\%) } \\
\text { Thrombocytopenia (8\%) } \\
\text { Allergic reaction (8\%) }\end{array}$ \\
\hline $\begin{array}{l}\text { Denduluri et al } \\
\text { 2007; No prior } \\
\text { taxane }\end{array}$ & 23 & $\begin{array}{l}6 \mathrm{mg} / \mathrm{m}^{2} / \text { day on days } \\
\mathrm{I}-5 \text { every } 3 \text { weeks }\end{array}$ & $\begin{array}{l}57 \%(95 \% \mathrm{Cl} \\
34.5 \%-76.8 \%)\end{array}$ & $\begin{array}{l}\text { Median time } \\
\text { to progression } \\
5.5 \text { months }\end{array}$ & $\begin{array}{l}\text { Neutropenia (22\%) } \\
\text { Thrombocytopenia (4\%) } \\
\text { Arthralgia/myalgia (4\%) } \\
\text { Diarrhea (4\%) } \\
\text { Fatigue (I3\%) } \\
\text { Motor neuropathy }(4 \%) \\
\text { Nausea }(9 \%)\end{array}$ \\
\hline $\begin{array}{l}\text { Perez et al } \\
\text { 2007; Prior } \\
\text { taxane }\end{array}$ & 126 & $\begin{array}{l}40 \mathrm{mg} / \mathrm{m}^{2} \text { every } \\
21 \text { days }\end{array}$ & $\begin{array}{l}\text { Independent radiology } \\
\text { facility II.5\% }(95 \% \mathrm{Cl} \\
6.3 \%-18.9 \%) \\
\text { Investigator assessed } \\
18.3 \%(95 \% \mathrm{Cl} \\
11.9 \%-26.1 \%)\end{array}$ & $\begin{array}{l}\text { Median progression- } \\
\text { free survival } \\
3 . I \text { months; median } \\
\text { overall survival } \\
8.6 \text { months }\end{array}$ & $\begin{array}{l}\text { Neutropenia (54\%) } \\
\text { Febrile neutropenia (3\%) } \\
\text { Thrombocytopenia (8\%) } \\
\text { Sensory neuropathy } \\
(14 \%) \\
\text { Fatigue/asthenia (14\%) } \\
\text { Myalgia/arthralgia (8\%) } \\
\text { Nausea (2\%) }\end{array}$ \\
\hline $\begin{array}{l}\text { Thomas et al } \\
\text { 2007; Prior } \\
\text { taxane }\end{array}$ & 49 & $\begin{array}{l}40 \mathrm{mg} / \mathrm{m}^{2} \text { every } \\
3 \text { weeks }\end{array}$ & $\begin{array}{l}12 \%(95 \% \mathrm{Cl} \\
4.7 \%-26.5 \%)\end{array}$ & $\begin{array}{l}\text { Median time to pro- } \\
\text { gression } 2.2 \text { months, } \\
\text { median survival } \\
7.9 \text { months }\end{array}$ & $\begin{array}{l}\text { Febrile neutropenia }(6 \%) \\
\text { Sensory neuropathy }(12 \% \\
\text { Fatigue ( } 27 \% \\
\text { Nausea/vomiting }(26 \%) \\
\text { Myalgia/arthralgia }(12 \%)\end{array}$ \\
\hline $\begin{array}{l}\text { Roche et al } \\
2007 \text {; Prior } \\
\text { adjuvant tax- } \\
\text { ane allowed if } \\
\geq \text { I year since } \\
\text { treatment }\end{array}$ & 93 & $\begin{array}{l}40 \mathrm{mg} / \mathrm{m}^{2} \text { every } \\
3 \text { weeks }\end{array}$ & $\begin{array}{l}41.5 \%(95 \% \mathrm{Cl} \\
29.4 \%-54.4 \%)\end{array}$ & $\begin{array}{l}\text { Median time to pro- } \\
\text { gression } 9.3 \text { months, } \\
\text { median survival } \\
29.9 \text { months }\end{array}$ & $\begin{array}{l}\text { Neutropenia }(58 \%) \\
\text { Febrile neutropenia }(6 \%) \\
\text { Seonsory neuropathy } \\
(20 \%) \\
\text { Motor neuropathy }(5 \%) \\
\text { Myalgia/arthralgia }(13 \%) \\
\text { Nausea/vomiting }(7 \%)\end{array}$ \\
\hline
\end{tabular}


$11.5 \%$ and the investigator-assessed ORR was $18.3 \%$. Stable disease was achieved in $50 \%$ of patients. The median overall survival was 8.6 months. The adverse effects encountered were generally managable. Grade 3 and 4 neutropenia was seen in about half the patients, but febrile neutropenia was uncommon. The most frequent nonhematologic toxicity was peripheral sensory neuropathy which was seen in $60 \%$, but this generally reversed after 5 weeks.

Another study using the same dose and schedule of ixabepilone was evaluated in taxane refractory patients (Thomas et al 2007). Of the 66 patients, $86 \%$ had received $\geq 2$ prior therapies and $98 \%$ of those patients had either docetaxel or paclitaxel as their most recent treatment in the metastatic setting. ORR was $12 \%$, similar to that in the Perez study, and stable disease was achieved in $41 \%$ of patients. Fifty-five percent of patients developed grade 1 or 2 toxicity. Serious adverse effects were seen in $22 \%$ of patients. This trial was initially designed to give $50 \mathrm{mg} / \mathrm{m}^{2}$ of ixabepilone over 1 hour, and $38 \%$ of patients at that dose developed grade 3 sensory neuropathy. When the dose was lowered to $40 \mathrm{mg} / \mathrm{m}^{2}$ and extended over a 3-hour infusion time, the incidence of severe neuropathy dropped to $12 \%$.

Ixabepilone has also been studied in the first-line metastatic setting (Roche et al 2007), with a $40 \mathrm{mg} / \mathrm{m}^{2}$ dose given as a 3-hour infusion every 3 weeks. All 65 patients had received anthracycline-based therapy in the adjuvant setting. The primary endpoint was objective response rate, which was determined as $41.5 \%$. There were no complete responses, but 27 patients had a partial response and 23 patients had stable disease. Median survival was 22 months. Similar to the other studies using this dosing schedule, toxicities were generally mild and managable. Twenty percent of patients developed grade 3 sensory neuropathy, and $51 \%$ had grade 1 or 2 sensory neuropathy. Although grade 3 or 4 neutropenia was seen in $58 \%$ of patients, only $6(9 \%)$ patients had febrile neutropenia or infections related to neutropenia.

\section{Activity in other tumor types}

Based on the activity of ixabepilone in a wide variety of tumor types in phase I studies, a number of phase II studies were designed to assess disease specific activity. In patients with nonsmall-cell lung cancer refractory to platinum drugs, ORR was $14.3 \%$ with 3 -weekly dosing and $11.6 \%$ with daily dosing for 5 days, which is similar to other second-line treatments in this disease. The toxicity profile was acceptable and included a $6 \%$ rate of grade 3 sensory neuropathy, and neutropenia was seen in $28 \%$ of patients receiving 3 -weekly dosing and in $17 \%$ of patients receiving daily dosing (Vansteenkiste et al 2007).
Acceptable response rates of $15 \%-48 \%$ with and without estramustine phosphate were seen in hormone-refractory prostate cancer. Grade 3 sensory neuropathy was seen in $13 \%-17 \%$ of patients and rates of grade $3 / 4$ neutropenia were 17\%-29\% (Galsky et al 2005; Hussain et al 2005). Modest activity was also seen in patients with prostate cancer in the second-line setting who had progressed on first-line docetaxel; however, half the patients developed grade 3/4 neutropenia (Rosenberg et al 2007). Final as well as preliminary phase II data with promising activity have also been presented in renal cell cancer (Fojo et al 2005), gynecologic cancers (Chen et al 2004), hepatobiliary cancer (Singh et al 2003), gastric cancer (Ajani et al 2006), pancreatic cancer (Whitehead et al 2006), and nonHodgkin's lymphoma (O'Connor et al 2005; Smith et al 2005).

Despite some suggestions of phase I activity, there has not been any meaningful efficacy in phase II studies in melanoma, colorectal cancer, and sarcoma (Eng et al 2004; Pavlick et al 2004; Okuno et al 2005).

\section{Phase III registration trial}

Based on preclinical data showing synergism between ixabepilone and capecitabine (Lee 2006) and the results of the phase I/II study discussed above (Bunnell et al 2006), a phase III study was designed to examine the response to the combination compared with single-agent capecitabine (Thomas et al 2007). In this trial, 752 patients were randomized to receive either capecitabine alone $\left(2500 \mathrm{mg} / \mathrm{m}^{2}\right.$ orally on days $1-14$ every 21 days) or capecitabine (2000 $\left.\mathrm{mg} / \mathrm{m}^{2}\right)$ in combination with ixabepilone $\left(40 \mathrm{mg} / \mathrm{m}^{2}\right.$ every 21 days). All patients had received prior anthracyclines and taxanes and almost half had received $\geq 2$ prior therapies for metastatic disease. Dose reductions of ixabepilone or capecitabine were required in approximately half the patients in the combination arm, whereas $37 \%$ of patients in the single-agent capecitabine arm required a dose reduction. The primary endpoint was progression-free survival, which was significantly improved in the combination therapy arm (5.8 months vs 4.2 months). The hazard ratio reflected a $25 \%$ improvement in the estimated risk of disease progression favoring the combination. The objective response rate was $35 \%$ with ixabepilone and capecitabine versus $14 \%$ with capecitabine alone $(\mathrm{p}<0.0001)$. In the combination arm $41 \%$ of patients had stable disease compared with $46 \%$ in the single-agent capecitabine arm. As expected, incidence of sensory neuropathy was greater in the combination arm, although rates of severe hand-foot syndrome and diarrhea were similar in each arm. Grades 3/4 neutropenia were more 
common in the combination arm, and any neutropenia was frequent in that arm (89\%). In the single-agent capecitabine $\operatorname{arm} 43 \%$ of patients had any level of neutropenia.

\section{Neoadjuvant trials}

Ixabepilone has been used in the neoadjuvant setting in breast cancer in addition to the metastatic setting. A preliminary report using a dose of $40 \mathrm{mg} / \mathrm{m}^{2}$ every 21 days revealed a pathologic complete response rate $(\mathrm{pCR})$ of $21 \%$ of patients. Approximately $50 \%$ of patients were ER+. Grade 3 or 4 neutropenia was seen in $21 \%$ and $13 \%$ of patients, respectively. Grade 2 neuropathy was seen in $11 \%$ of patients, whereas grade 3 neuropathy was seen in $2 \%$ (Baselga et al 2005). Correlative studies revealed a 6 gene predictive model that was able to predict benefit to ixabepilone (Llmobart-Cussac et al 2005). Other preliminary data suggest a higher response rate in the triple negative (ER, PR, and HER2 negative) subgroup of breast cancer patients, with a pCR rate of $26 \%$ of the 42 triple negative patients and $15 \%$ in the 119 other patients given neoadjuvant ixabepilone (Roche et al 2006).

\section{Safety}

As evidenced in phase I and II trials, neuropathy and neutropenia are important potential toxicities. The neuropathy is primarily sensory and generally reversible in most patients with proper dose reductions and drug discontinuation (Perez et al 2007; Thomas et al 2007). Patients with diabetes have been shown to be at increased risk for the development of neuropathy and it is important to note that because patients with pre-existing neuropathy were excluded from clinical trials, their potential severity of neuropathy is unknown. Numerically it appears that daily dosing (Abraham et al 2003; Low et al 2005; Denduluri et al 2007a; Denduluri et al 2007b) may be associated with less severe neuropathy (grade 3 neuropathy in 3\%-4\%) than in 3-weekly dosing (grade 3 in 13\%-23\%) (Perez et al 2007; Roche et al 2007; Thomas et al 2007). However, a study in nonsmall-lung cancer did not show any differences in neuropathy between 3 -weekly and daily dosing (Vansteenkiste et al 2007). The use of specific neurologic function tests to characterize the neuropathy associated with ixabepilone has been described (Lee et al 2006). The patients enrolled in a monotherapy trial of ixabepilone in breast cancer (Low et al 2005) had a number of neurologic function tests performed, including Semmes-Weinstein monofilament testing and modified Romberg stance tests, which are used to assess diabetic neuropathy, and the Jebsen Test of Hand Function (JTH) and Grooved Pegboard Test (GPT), which are used to assess hand functions particularly in patients with stroke and rheumatoid arthritis. Twenty-three percent of patients developed $\geq$ grade 2 neuropathy (including decreased hand function, decreased sensory function, paresthesias, and motor weakness), 9 patients developing grade 2 neuropathy and 2 patients developing grade 3 neuropathy. Three patients had refractory neuropathy that did not resolve to grade 1 up to 2 years after development. The results of JTH and GPT scores were found to be identifiable with onset of grade 12 or higher peripheral neuropathy.

The most common overall adverse reactions seen in the monotherapy registration trial are summarized in Table 3 (Perez et al 2007). When combined with capecitabine, toxicities commonly encountered with capecitabine such as palmar-plantar erythrodysesthesia and diarrhea were not significantly increased. It is recommended that patients with known severe hypersensitivity to Cremophor ${ }^{\circledR}$ EL or derivatives, baseline ANC $<1500$ cells $/ \mathrm{mm}^{3}$, platelets $<100,000$ cells $/ \mathrm{mm}^{3}$, or abnormal liver function (transaminases $>2.5 \times \mathrm{ULN}$ or bilirubin $>1 \times \mathrm{ULN}$ ) do not receive ixabepilone.

\section{Conclusions}

Ixabepilone is an important addition to chemotherapeutic options for patients with MBC. The activity in patients who have failed previous taxanes makes this drug applicable for virtually all patients with $\mathrm{MBC}$ at some time in the course of their treatment. The high level of activity in the first-line setting makes it an attractive option in that setting as well. The results of ongoing trials exploring the additional of various biologic agents, such as trastuzumab and bevacizumab, are eagerly awaited (Cancer.gov 2008a, b, c). The strategy of combining chemotherapy with antiangiogenic agents is increasingly being used especially in the first-line setting for

Table 3 Nonhematologic adverse events seen in monotherapy registration trial

\begin{tabular}{lll}
\hline $\begin{array}{l}\text { Nonhematologic } \\
\text { adverse event }\end{array}$ & $\begin{array}{l}\text { Total (\%) } \\
(\mathbf{n}=\mathbf{~ 1 2 6 )}\end{array}$ & Grade 3/4 (\%) \\
\hline Peripheral sensory neuropathy & 60 & 14 \\
Fatigue/asthenia & 56 & 13 \\
Myalgia/arthralgia & 49 & 8 \\
Alopecia & 48 & 0 \\
Nausea & 42 & 2 \\
Stomatitis/mucositis & 29 & 6 \\
Vomiting & 29 & 1 \\
Diarrhea & 22 & 1 \\
Musculoskeletal pain & 20 & 3 \\
\hline
\end{tabular}


$\mathrm{MBC}$ and the potential for improved activity exists with the other novel microtubule agents (Miller et al 2007). The taxanes in particular may potentiate the anti-angiogenic effects of these agents (Miller et al 2001; Sweeney et al 2001). A phase III trial conducted by the Cancer and Leukemia Group B (CALGB) and the North Central Cancer Treatment Group (NCCTG) is currently underway comparing the activity of various microtubule stabilizing agents with the vascular endothelial growth factor antibody bevacizumab. This trial is comparing weekly paclitaxel $\left(90 \mathrm{mg} / \mathrm{m}^{2}\right)$, nabpaclitaxel $\left(100 \mathrm{mg} / \mathrm{m}^{2}\right)$, and ixabepilone $\left(16 \mathrm{mg} / \mathrm{m}^{2}\right)$ in combination with bevacizumab. This trial will also supply important information on the activity of these agents given in a "dose-dense" fashion, in which paclitaxel and arguably nab-paclitaxel have been found to have the greatest activity (Gradishar et al 2006; Seidman et al 2008; Sparano et al 2008). There are a number of other agents that target the angiogenic as well as other important pathways with recent promising data (Rugo et al 2007) (Burstein et al 2008), and these agents may provide other rational combinations with ixabepilone. With the advent of new and possibly improved taxane agents, the question will be in what setting are these agents best used and whether they would replace traditional taxanes as the preference for first-line therapy; or whether, perhaps because of activity in docetaxel- and paclitaxelresistant patients, their activity may be best reserved for patient with refractory disease. The role of ixabepilone will be best ascertained when it is directly compared with the other available taxanes in a variety of dosing schedules and lines of therapy. These questions will be best answered in the setting of a phase III randomized trial such as the CALGB/NCCTG one described above.

\section{Disclosures}

Neither author has any financial disclosures related to any product discussed in this review.

\section{References}

Cancer.gov. 2008a. A phase II combination of trastuzumab and ixabepilone versus trastuzumab and docetaxel in patients with advanced and/or metastatic breast cancer. Accessed 2 January 2008. URL: http://www. cancer.gov/search $/$ ViewClinicalTrials.aspx?cdrid $=558843 \&$ version $=$ HealthProfessional\&protocolsearchid $=4256672$.

Cancer.gov. 2008b. Phase II study of trastuzumab (herceptin) and ixabepilone (BMS-247550) in women with HER2-positive metastatic breast cancer. Accessed 2 January. 2008. URL: http://www.cancer. gov/search/ViewClinicalTrials.aspx?cdrid=355176\&version=Health Professional\&protocolsearchid $=4352712$.

Cancer.gov. 2008c. A trial of 2 schedules of ixabepilone plus bevacizumab and paclitaxel plus bevacizumab for breast cancer. Accessed 2 January 2008. URL: http://www.cancer.gov/search/ViewClinicalTrials.aspx?cdrid= $355176 \&$ version $=$ HealthProfessional\&protocolsearchid $=4256672$.
Abraham J, Agrawal M, Bakke S, et al. 2003. Phase I trial and pharmacokinetic study of BMS-247550, an epothilone B analog, administered intravenously on a daily schedule for five days. J Clin Oncol, 21:1866-73.

Aghajanian C, Burris HA 3rd, Jones S, et al. 2007. Phase I study of the novel epothilone analog ixabepilone (BMS-247550) in patients with advanced solid tumors and lymphomas. J Clin Oncol, 25:1082-8.

Ajani JA, Safran H, Bokemeyer C, et al. 2006. A multi-center phase II study of BMS-247550 (Ixabepilone) by two schedules in patients with metastatic gastric adenocarcinoma previously treated with a taxane. Invest New Drugs, 24:441-6.

Anderson S, Dizon D, Sabbatini J, et al. 2004. Phase I trial of BMS-247550 and gemcitabine in patients with advanced solid tumor malignancies. Proc Am Soc Clin Oncol, 22:abstract 2098.

Awada A, Bleiberg H, deValeriola D, et al. 2001. Phase I clinical and pharmacology study of the epothilone analog BMS-247550 given weekly in patinets (pts) with advanced solid tumors. Proc Am Soc Clin Oncol:abstract 427.

Baselga J, Gianni L, Llombart A, et al. 2005. Predicting repsonse to ixabepilone: genomics study in patients receiving single agent ixabepilone as neoadjuvant treatment for breast cancer (BC). Breast Cancer Res Treat, 94:s31-s32.

Bode CJ, Gupta ML Jr, Reiff EA, et al. 2002. Epothilone and paclitaxel: unexpected differences in promoting the assembly and stabilization of yeast microtubules. Biochemistry, 41:3870-4.

Bollag DM, McQueney PA, Zhu J, et al. 1995. Epothilones, a new class of microtubule-stabilizing agents with a taxol-like mechanism of action. Cancer Res, 55:2325-33.

Bunnell CA, Klimovsky J, Thomas E. 2006. Final efficacy results of a phase I/II trial of ixabepilone in combination with capecitabine in patients with metastatic breast cancer (MBC) previously treated with a taxane and an anthracycline. Proc Am Soc Clin Oncol, 24:abstract 10511.

Burris HA, Awada A, Jones S, et al. 2002. Phase I study of the novel epothilone BMS-247550 administered weekly in patietns (pts) with advanced malignancies. Proc Am Soc Clin Oncol:abstract 412.

Burstein HJ, Elias AD, Rugo HS, et al. 2008. Phase II study of sunitinib malate, an oral multitargeted tyrosine kinase inhibitor, in patients with metastatic breast cancer previously treated with an anthracycline and a taxane. J Clin Oncol, 26:1810-6.

Chen T, Molina A, Moore S, et al. 2004. Epithilone B analog (BMS-247550) at the recommended Phase II dose (RPTD) in patients (pts) with gynecologic (gyn) and breast cancers. J Clin Oncol, 23:abstract 2115.

Denduluri N, Lee JJ, Walshe J, et al. 2007b. Phase II trial of ixabepilone, an epothilone B analog, given daily for three days every three weeks, in metastatic breast cancer. Invest New Drugs, 25:63-7.

Denduluri N, Low JA, Lee JJ, et al. 2007a. Phase II trial of ixabepilone, an epothilone $\mathrm{B}$ analog, in patients with metastatic breast cancer previously untreated with taxanes. J Clin Oncol, 25:3421-7.

Eng C, Kindler HL, Nattam S, et al. 2004. A phase II trial of the epothilone B analog, BMS-247550, in patients with previously treated advanced colorectal cancer. Ann Oncol, 15:928-32.

Fojo AT, Menefee M, Poruchynsky M, et al. 2005. A translational study of ixabepilone (BMS-247550) in renal cell cancer (RCC): assessment of its activity and demonstration of target engagement in tumor cells. $J$ Clin Oncol, 23:abstract 4541.

Fumoleau P, Coudert B, Isambert N, et al. 2007. Novel tubulin-targeting agents: anticancer activity and pharmacologic profile of epothilones and related analogues. Ann Oncol, 18(Suppl 5):v9-15.

Gadgeel SM, Wozniak A, Boinpally RR, et al. 2005. Phase I clinical trial of BMS-247550, a derivative of epothilone B, using accelerated titration 2B design. Clin Cancer Res, 11:6233-9.

Galsky MD, Small EJ, Oh WK, et al. 2005. Multi-institutional randomized phase II trial of the epothilone B analog ixabepilone (BMS-247550) with or without estramustine phosphate in patients with progressive castrate metastatic prostate cancer. $J$ Clin Oncol, 23:1439-46.

Gerth K, Bedorf N, Hofle G, et al. 1996. Epothilons A and B: antifungal and cytotoxic compounds from Sorangium cellulosum (Myxobacteria). Production, physico-chemical and biological properties. J Antibiot (Tokyo), 49:560-3. 
Giannakakou P, Gussio R, Nogales E, et al. 2000. A common pharmacophore for epothilone and taxanes: molecular basis for drug resistance conferred by tubulin mutations in human cancer cells. Proc Natl Acad Sci USA, 97:2904-9.

Gradishar WJ, Krasnojon D, Cheporov S, et al. 2006. A randomized phase 2 trial of qw or q3w ABI-007 (ABX) vs. q3w solvent based docetaxel (TXT) as first-line therapy in metastatic breast cancer (MBC). Breast Cancer Res Treat, s21:abstract 46.

Gradishar WJ, Tjulandin S, Davidson N, et al. 2005. Phase III trial of nanoparticle albumin-bound paclitaxel compared with polyethylated castor oil-based paclitaxel in women with breast cancer. J Clin Oncol, 23:7794-803.

Hao D, Hammond LA, deBono JS, et al. 2002. Continuous weekly administration of the epothilone-B derivative, BMS247,550 (NSC710428): a phase I and pharmacokinetic (PK) study. Proc Am Soc Clin Oncol, 21:abstract 411.

He L, Orr GA, Horwitz SB. 2001a. Novel molecules that interact with microtubules and have functional activity similar to taxol. Drug Discov Today, 6:1153-64.

He L, Yang CP, Horwitz SB. 2001b. Mutations in beta-tubulin map to domains involved in regulation of microtubule stability in epothiloneresistant cell lines. Mol Cancer Ther, 1:3-10.

Hensley ML, Dizon D, Derosa F, et al. 2007. A phase I trial of BMS-247550 (NSC\# 710428) and gemcitabine in patients with advanced solid tumors. Invest New Drugs, 25:335-41.

Hussain M, Tangen CM, Lara PN Jr, et al. 2005. Ixabepilone (epothilone B analogue BMS-247550) is active in chemotherapy-naive patients with hormone-refractory prostate cancer: a Southwest Oncology Group trial S0111. J Clin Oncol, 23:8724-9.

Jordan MA, Wilson L. 2004. Microtubules as a target for anticancer drugs. Nat Rev Cancer, 4:253-65.

Lee FY, Borzilleri R, Fairchild CR, et al. 2001. BMS-247550: a novel epothilone analog with a mode of action similar to paclitaxel but possessing superior antitumor efficacy. Clin Cancer Res, 7:1429-37.

Lee FY, Camuso A, Castenada S, et al. 2006. Preclinical studies of ixabepilone (BMS-247550) demonstrate optimal antitumor activity against both chemotherapy-sensitive and -resistant tumor types [abstract]. Proceedings 97th Annual Meeting of the American Association for Cancer Research; 2006 Apr 1-5; Washington DC. Philadelphia (PA). abstract 503.

Lee FY, Camuso A, Castenada C, et al. 2006. Preclinical efficacy evaluation of ixbepilone (BMS-247550) in combination with cetuximab or capecitabine in human colon and lung carcinoma xenografts. $J$ Clin Oncol, 24:abstract 12017.

Lee JJ, Low JA, Croarkin E, et al. 2006. Changes in neurologic function tests may predict neurotoxicity caused by ixabepilone. J Clin Oncol, 24:2084-91.

Llmobart-Cussac A, Baselga G, Manikhas G, et al. 2005. Phase II genomics study in patients receiving Ixabepilone as neoadjuvant treatment for breast cancer $(\mathrm{BC})$ : Preliminary efficacy and safety data. $J$ Clin Oncol, 23:abstract 586.

Low JA, Wedam SB, Lee JJ, et al. 2005. Phase II clinical trial of ixabepilone (BMS-247550), an epothilone B analog, in metastatic and locally advanced breast cancer. J Clin Oncol, 23:2726-34.

McDaid HM, Mani S, Shen HJ, et al. 2002. Validation of the pharmacodynamics of BMS-247550, an analogue of epothilone B, during a phase I clinical study. Clin Cancer Res, 8:2035-43.

Mani S, McDaid H, Hamilton A, et al. 2004. Phase I clinical and pharmacokinetic study of BMS-247550, a novel derivative of epothilone B, in solid tumors. Clin Cancer Res, 10:1289-98.

Mani S, McDaid HM, Grossman A, et al. 2007. Peripheral blood mononuclear and tumor cell pharmacodynamics of the novel epothilone B analogue, ixabepilone. Ann Oncol, 18:190-5.

Miller K, Wang M, Gralow J, et al. 2007. Paclitaxel plus bevacizumab versus paclitaxel alone for metastatic breast cancer. $N$ Engl $J$ Med, 357:2666-76.

Miller KD, Sweeney CJ, Sledge GW Jr, et al. 2001. Redefining the target: chemotherapeutics as antiangiogenics. J Clin Oncol, 19:1195-206.
Nogales E, Wolf SG, Khan I, et al. 1995. Structure of tubulin at 6.5 A and location of the Taxol-binding site. Nature, 375:424-7.

O'Connor OA, Straus D, Moskowitz C, et al. 2005. Targeting the microtubule apparatus in indolent and mantle cell lymphoma with the novel epothilone analog BMS 247550 induces major and durable remissions in very drug resistant disease. J Clin Oncol, 23: abstract 6569.

Ojima I, Chakravarty S, Inoue T, et al. 1999. A common pharmacophore for cytotoxic natural products that stabilize microtubules. Proc Natl Acad Sci USA, 96:4256-61.

Okuno S, Maples WJ, Mahoney MR, et al. 2005. Evaluation of epothilone B analog in advanced soft tissue sarcoma: a phase II study of the phase II consortium. J Clin Oncol, 23:3069-73.

Pavlick AC, Millward M, Farrell K, et al. 2004. A phase II study of the epothilone B analog (EpoB)-BMS 247550 (NSC710428) in stage IV malignant melanoma. J Clin Oncol, 23:abstract 7542.

Perez EA, Lerzo G, Pivot X, et al. 2007. Efficacy and safety of ixabepilone (BMS-247550) in a phase II study of patients with advanced breast cancer resistant to an anthracycline, a taxane, and capecitabine. J Clin Oncol, 25:3407-14.

Plummer R, Molife R, Verrill M, et al. 2002. Phase I and pharmacokinetic study of BMS-247550 in combination with carboplatin in patients with advanced solid malignancies. Proc Am Soc Clin Oncol, 21: abstract 2125 .

Roche H, Perez EA, Llombart-Cussac A, et al. 2006. Ixabepilone, an epothilone B analog, is effective in ER, PR, and HER-2 negative (triple negative) patinets (pts): Data from neoadjuvant and metastatic breast cancer (MBC) trials. Ann Oncol, 17:abstract 256P.

Roche H, Yelle L, Cognetti F, et al. 2007. Phase II clinical trial of ixabepilone (BMS-247550), an epothilone B analog, as first-line therapy in patients with metastatic breast cancer previously treated with anthracycline chemotherapy. J Clin Oncol, 25:3415-20.

Rosenberg JE, Weinberg VK, Kelly WK, et al. 2007. Activity of second-line chemotherapy in docetaxel-refractory hormone-refractory prostate cancer patients: randomized phase 2 study of ixabepilone or mitoxantrone and prednisone. Cancer, 110:556-63.

Rugo HS, Stopeck A, Joy AA, et al. 2007. A radomized, double-blind phase II study of the oral tyrosine kinase inhibitor (TKI) axitinib (AG-013736) in combination with docetaxel (DOC) compared to DOC plus placebo (PL) in metastatic breast cancer (MBC). Proc Am Soc Clin Oncol, 25: abstract 1003 .

Seidman AD, Berry D, Cirrincione C, et al. 2008. Randomized phase III trial of weekly compared with every-3-weeks paclitaxel for metastatic breast cancer, with trastuzumab for all HER-2 overexpressors and random assignment to trastuzumab or not in HER-2 nonoverexpressors: final results of the Cancer and Leukemia Group B protocol 9840. J Clin Oncol, 26:1642-9.

Shimizu T, Yamamoto N, Yamada Y, et al. 2008. Phase I clinical and pharmacokinetic study of 3-weekly, 3-h infusion of ixabepilone (BMS247550), an epothilone B analog, in Japanese patients with refractory solid tumors. Cancer Chemother Pharmacol, 61:751-8.

Singh DA, Kindler HL, Eng C, et al. 2003. Phase II trial of the epothilone B analog BMS-247550 in patients with hepatobiliary cancer. Proc Am Soc Clin Oncol, 22:abstract 1127.

Smith SM, Pro B, Van Besien K, et al. 2005. A phase II study of epothilone B analog BMS-247550 (NSC 710428) in patients with relapsed aggressive non-Hodgkin's lymphoma. J Clin Oncol, 23:abstract 6625.

Sparano JA, Wang M, Martino S, et al. 2008. Weekly paclitaxel in the adjuvant treatment of breast cancer. N Engl J Med, 358:1663-71.

Spriggs D, Soignet S, Bienvenu B, et al. 2001. Phase I first-in-man study of the epothilone B Analog BMS-247550 in patients with advanced cancer. Proc Am Soc Clin Oncol, 20:abstract 428.

Sweeney CJ, Miller KD, Sissons SE, et al. 2001. The antiangiogenic property of docetaxel is synergsitic with a recombinant humanized monoclonal antobody against vascular endothelial growth factor or 2-methoxyestradiol but antagonized by endothelial growht factors. Cancer Res, 61:3369-72. 
Thambi PM, Edgerly M, Agarwal M, et al. 2003. A phase I clinical trial of BMS-247550 (NSC 71028), an epothilone B derivative, given daily for 3 days on a 21 day cycle in patients with refractory neoplasms. Proc Am Soc Clin Oncol, 22:abstract 540.

Thomas E, Tabernero J, Fornier M, et al. 2007. Phase II clinical trial of ixabepilone (BMS-247550), an epothilone B analog, in patients with taxane-resistant metastatic breast cancer. J Clin Oncol, 25:3399-406.

Thomas ES, Gomez HL, Li RK, et al. 2007. Ixabepilone plus capecitabine for metastatic breast cancer progressing after anthracycline and taxane treatment. J Clin Oncol, 25:5210-7.
Vansteenkiste J, Lara PN Jr, Le Chevalier T, et al. 2007. Phase II clinical trial of the epothilone B analog, ixabepilone, in patients with non smallcell lung cancer whose tumors have failed first-line platinum-based chemotherapy. J Clin Oncol, 25:3448-55.

Whitehead RP, McCoy S, Rivkin SE, et al. 2006. A Phase II trial of epothilone B analogue BMS-247550 (NSC \#710428) ixabepilone, in patients with advanced pancreas cancer: a Southwest Oncology Group study. Invest New Drugs, 24:515-20.

Zhuang SH, Agrawal M, Edgerly M, et al. 2005. A Phase I clinical trial of ixabepilone (BMS-247550), an epothilone B analog, administered intravenously on a daily schedule for 3 days. Cancer, 103:1932-8. 
